\title{
First report of Perkinsus sp. infection in the bivalve Magallana bilineata (Roding, 1798) from Pulicat Lake, Tamil Nadu, south-east coast region of India
}

\author{
A. UMA, P. KARTHIK, J. PRAVEEN RAJ* AND G. REBECCA \\ State Referral Laboratory for Aquatic Animal Health, Tamil Nadu Dr. J. Jayalalithaa Fisheries University \\ Madhavaram Campus, Chennai - 600 051, Tamil Nadu, India \\ *ICAR-Central Island Agricultural Research Institute, Port Blair - 744 101, Andaman and Nicobar Islands, India \\ e-mail: srlfda.frec@gmail.com
}

\begin{abstract}
Perkinsus sp., an important protozoan parasite of mollusca is reported in the bivalve Magallana bilineata (Roding, 1798) for the first time from Pulicat Lake, Thiruvallur District, Tamil Nadu, south-east coast of India. Molluscs collected from Pulicat Lake were screened for Perkinsus sp. as part of a state-wide aquatic animal disease surveillance programme. Perkinsus sp. infection was diagnosed based on culture in Ray's Fluid Thioglycolate Medium (RFTM), histology as well as by molecular analyses. Microscopic analysis of the RFTM supernatant revealed enlarged blue-black hypnospores characteristic of Perkinsus sp. like organisms and typical 'signet ring' stages of trophozoites. Histological preparation of the molluscan gills also revealed trophozoites. PCR amplification of genomic DNA isolated from infected specimens using specific internal transcribed spacer (ITS) 85 and ITS 750 primers resulted in 703 bp DNA fragments specific for Perkinsus sp. BLAST analysis of the sequence revealed $97 \%$ homology with Perkinus marinus.
\end{abstract}

Keywords: Dermocystidium, OIE, Perkinsus marinus, Protozoan parasite

Perkinsosis, a significant infection caused by the protozoan parasites of the genus Perkinsus causes mass mortality in the farmed and wild marine molluscs including mussels, abalones, clams, scallops, pearl oysters, cockles and oysters (Villalba et al., 2004, Yadavalli et al., 2020). Seven species have been described, viz., Perkinsus marinus (Mackin et al., 1950), P. olseni (Lester and Davis, 1981), P. quagwadi (Blackbourn et al., 1998), P. chesapeaki (McLaughlin et al., 2000), P. mediterraneus (Casas et al., 2004), P. honshuensis (Dungan and Reece, 2006) and P. beihaiensis (Moss et al., 2008). P. marinus previously known as Dermocystidium marinum was the first species to be described (Mackin, et al., 1950; Perkins, 1968; 1988). Transmission of Perkinsus spp. occurs without intermediate hosts (Ray, 1954; Goggin and Lester, 1995; Chu, 1996; Blackbourn et al., 1998). Perkinsus spp. have three main life stages: trophozoites stage, which occurs in the tissues of the live host (Goggin and Lester, 1995; Perkins, 1996; Blackbourn et al., 1998); hypnospore stage, where thick wall is developed by the trophozoites (Ray, 1952) and zoospore stage, where hundreds of zoosporangium are formed within the cell wall (Perkins and Menzel, 1966).

The total world production of molluses from marine and coastal aquaculture is 16.4 million $\mathrm{t}$ and the contribution from Asia is 14.94 million t (FAO, 2017). Molluscan farming, which used to count for about 30\% of the total farmed food fish production around the year
2000, has gradually declined to $21 \%$ in 2015 (FAO, 2017). Though India has a vast potential for molluscan culture comprising of edible oyster, mussel, pearl oyster, abalone and clams, no commercial production of any groups of molluscs is undertaken on a large scale. Throughout the world, there have been many reports of mass mortalities in the farmed and wild bivalves due to various protozoan infections which caused substantial losses for the associated industries (Soniat, 1996). Periodical disease surveillance was undertaken on a monthly basis by the State Referral Laboratory for Aquatic Animal Health of Tamil Nadu Dr. J. Jayalalithaa Fisheries University to screen the molluscs for the OIE-listed Perkinsus infection along the coast of Pulicat Lake, south-east coast region of India. The diagnosis revealed the presence and confirmation of Perkinsus sp. in the bivalve Magallana bilineata (Roding, 1798) from Pulicat Lake. This constitutes the first report on the detection of Perkinsus sp. in molluscs from the south-east coast of India.

Mollusc samples were randomly collected irrespective of the genus, comprising of Volegalea cochlidium, Magallana bilineata, Mytilus sp., Babylonia zeylanica and Pugilina conchlidium from the Karimanal Lagoon located in Pulicat Lake, Thiruvallur District (1326'43.41'N; 80¹9'32.05”E) (Fig. 1). The collected samples were transported live in aerated bags to the laboratory for diagnosis. Of the 60 individuals collected 


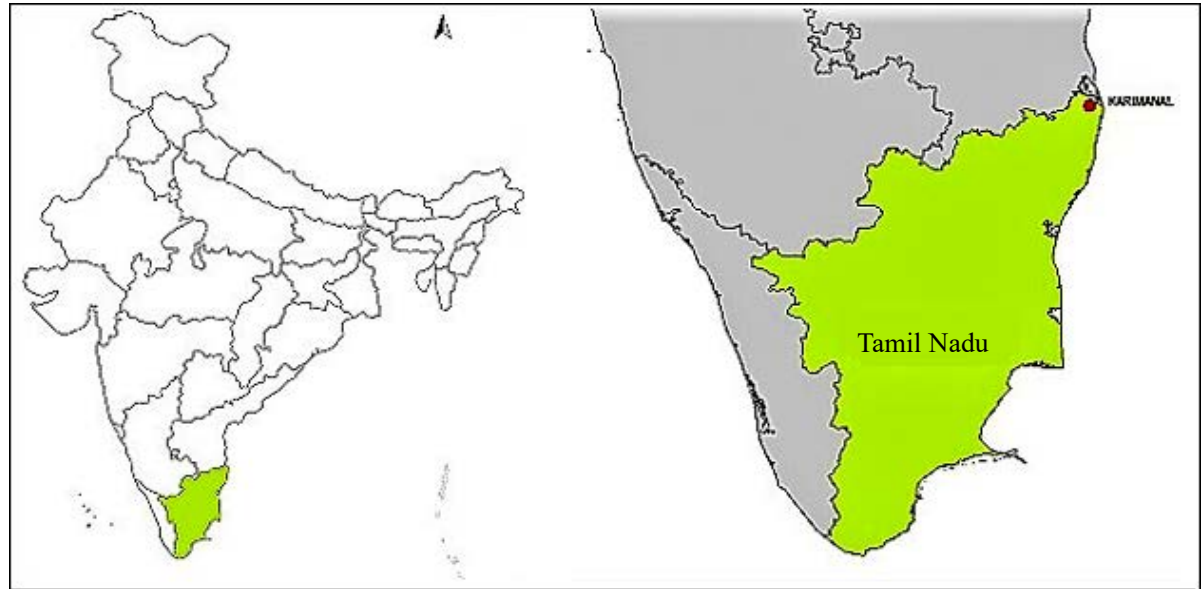

Fig. 1. Map showing the sampling site at Karimanal, Pulicat Lake, Tiruvallur District, Tamil Nadu (lat. 13.44123; long. 80.31782)

comprising of the aforesaid genus, five individuals were of adult $M$. bilineata. The samples were examined under stereomicroscope (Accu-Scope, USA) for any abnormality, fouling, shell damage, gaping, retraction of mantle, fluid accumulation, abscess and lesions.

About $5 \mathrm{~mm}$ of the gill and mantle tissue samples were excised and placed in individual $30 \mathrm{ml}$ tubes containing $15 \mathrm{ml}$ Ray's fluid thioglycollate medium (RFTM) supplemented with antibiotics to inhibit the growth of bacterial and fungal organisms (OIE, 2006; Ray, 1966). The tubes were incubated in the dark at $24^{\circ} \mathrm{C}$ for 7 days. After incubation, the fragments of tissue and the supernatant from each tube were collected and placed on a glass slide, stained directly with both Lugol's iodine and haematoxylin solution and examined under the microscope $(100 \mathrm{x})$ for the presence of spores.

Mantle tissue and gills were fixed in Davidson's fixative for $24 \mathrm{~h}$, transferred to $70 \%$ alcohol, dehydrated in ethanol series, cleared, embedded in paraffin and $5 \mu \mathrm{m}$ thick sections were made using a Microtome (Leica, Wetzlar, Germany) and processed for histopathology following standard methods (Roberts, 2012). The sections were stained using Harris haematoxylin and eosin (H\&E) and examined under a light microscope (Leica DMLS, Wetzlar, Germany).

The mantle tissue and the gills were aseptically excised and fixed in absolute ethanol for DNA extraction. PCR screening of Perkinsus sp. was carried out using primers targeting ITS 85 and ITS 750 (Casas et al., 2002). PCR amplification reaction was carried out in a thermal cycler (Bio-rad T100 Thermal cycler, USA) in a total volume of $25 \mu \mathrm{l}$ reaction mixture containing $10 \mu \mathrm{l}$ of master mix (Ampliqon Taq DNA polymerase, $2.0 \mathrm{x}$ Master mix red, $\left.\mathrm{MgCl}_{2} 2.0 \mathrm{mM}\right), 12 \mu \mathrm{l}$ of nuclease free water, $1.0 \mu \mathrm{l}(10 \mathrm{pmol})$ of forward and reverse primer each and $1.0 \mu \mathrm{l}(50 \mathrm{ng})$ of sample DNA. The PCR cycling conditions followed was initial denaturation at $95^{\circ} \mathrm{C}$ for 5 min followed by 35 cycles of denaturation at $94^{\circ} \mathrm{C}$ for $20 \mathrm{~s}$, annealing of primers at $58^{\circ} \mathrm{C}$ for $20 \mathrm{~s}$ and extension at $72^{\circ} \mathrm{C}$ for $45 \mathrm{~s}$ with a final extension at $72^{\circ} \mathrm{C}$ for $5 \mathrm{~min}$. The PCR products were separated by electrophoresis in an agarose gel $(1.2 \%)$ stained with ethidium bromide $\left(0.5 \mu \mathrm{g} \mathrm{ml}^{-1}\right)$ and visualised using a gel documentation system (Bio-Rad, USA). The amplified PCR products were sequenced (Eurofins, Bangalore) and homology of the generated sequence was analysed using the Basic Local Alignment Search Tool (BLAST) program in the National Centre for Biotechnology Information (NCBI) following Altschul et al. (1990).

The internal transcribed spacer (ITS) sequences for the known Perkinsus spp. sequences retrieved from NCBI GenBank were used for constructing the phylogenetic tree (see appendix for the list of sequences used). The retrieved sequences along with the sequence generated in the present study were aligned using clustalW (Thompson et al., 1994). Pairwise genetic distances between the present species and other Perkinsus sp. were calculated based on Kimura 2 parameter model (Kimura, 1980), using MEGA7 (Kumar et al., 2016). The Best fit nucleotide substitution model was selected from 24 models, based on the one with the lowest BIC scores (Bayesian Information Criterion) which are considered to describe the substitution pattern the best (Nei and Kumar, 2000). The phylogenetic tree was constructed using maximum likelihood model present in MEGA7. Reliability of the phylogenetic tree was estimated using bootstrap values run for 1000 iterations.

Visual observation of all the samples with the aid of a stereozoom microscope revealed remarkably emaciated muscle mass only in the mantle of $M$. bilineata, whereas other bivalves and gastropods did not show up any significant difference. 
The supernatant from RFTM inoculated with $M$. bilineata mantle and gill tissues showed enlarged blue-black hypnospores characteristic of Perkinsus sp. like organisms (Fig. 2a). Typical 'signet ring' stages of trophozoites were observed from 4 to $8^{\text {th }}$ day in the slides stained with Lugol's iodine (Fig. 2b, c, d). From day 12 onwards, maturing zoosporangia containing numerous internal zoosporoblast cells that are subdividing towards maturation as motile zoospores were observed (Fig. 2e). On day 13 and 14, zoosporangium containing numerous zoospores with some leaving the sporangium were observed (Fig. 2f).

Trophozoites with vacoulation of the muscle fibre and degenerative necrosis were observed in the muscle of the infected M. bilineata (Fig. 3a). Degenerative necrotic changes of the gill filaments with trophozoites of the parasite were observed in the histological section of the gills of the infected samples (Fig. 3b).

The PCR screening of the samples with Perkinsus sp. specific primers targeting ITS amplified a DNA product of $703 \mathrm{bp}$ (Fig. 4). The PCR product was further confirmed by sequencing and BLAST analysis in NCBI. The BLAST results showed $97 \%$ identity to $P$. marinus sequences present in the NCBI GenBank. The nucleotide sequence generated in the present study was deposited in NCBI GenBank with Accession No. MH542429.

The Best-fit model test for phylogenetic analysis suggested the Kimura 2-parameter model (K2-P) as the best nucleotide substitution model with the lowest
BIC scores (Bayesian Information Criterion), corrected AIC value (Akaike information criterion) and a Gamma parameter $(\mathrm{HKY}+\mathrm{G}+\mathrm{I}, \mathrm{BIC}=5070.844, \mathrm{AICc}=4717.066$, $\ln L=-2311.369,(+\mathrm{G})=1.18)$. The maximum likelihood tree based on the K2-P model suggests that genetically the closet relative for the present Perkinsus sp. is $P$. marinus from which it differs from a pair-wise sequence of 3.7-3.9\% (Fig. 5).

The present study confirms the presence of the protozoan parasite Perkinsus sp. in M. bilineata collected from Pulicat Lake of Tamil Nadu, India based on RFTM culture as well as by histopathological, PCR and sequence analyss. This is the first report of Perkinsus sp.

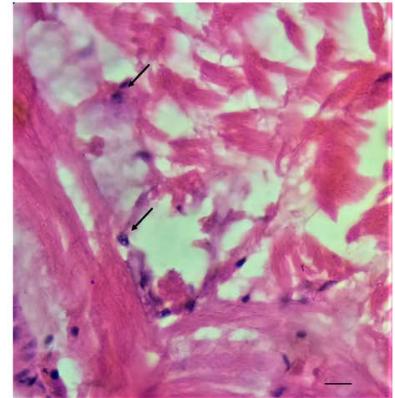

(a)

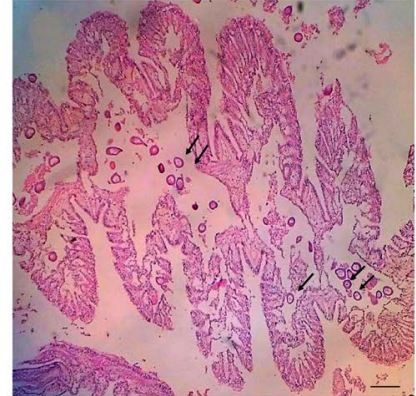

(b)
Fig. 3. Histological sections of mantle/gill tissues of M. bilineata. a. Arrows show trophozoites with vacoulation of the muscle fibre (H\&E; scale bar $=20 \mu \mathrm{m}) ; \mathrm{b}$. Arrows show trophozoites in the gills $(\mathrm{H} \& \mathrm{E} ;$ scale bar $=150 \mu \mathrm{m})$

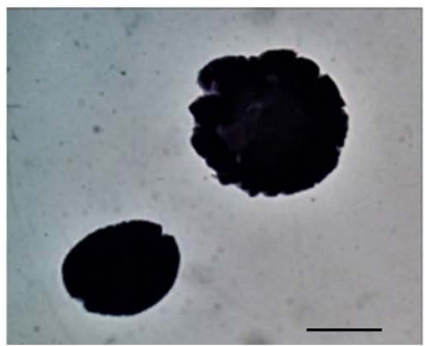

(a)

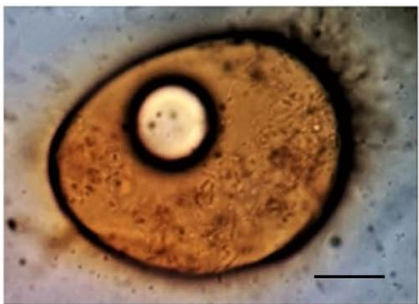

(d)

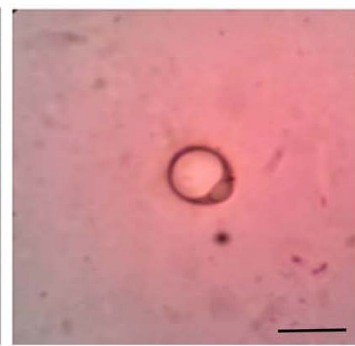

(b)

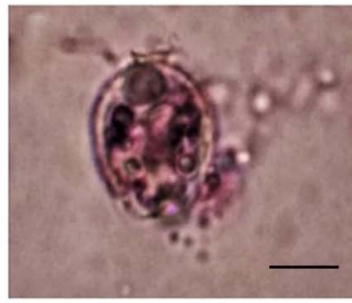

(e)

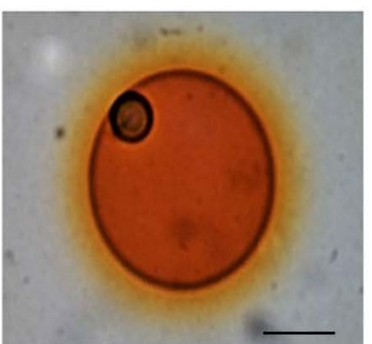

(c)

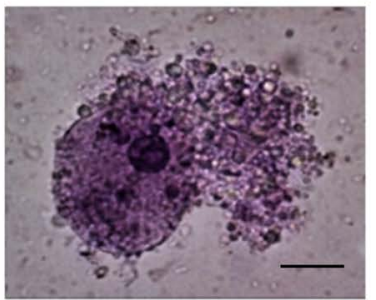

(f)

Fig. 2. Microscopic observation of Perkinsus sp. cultured by RFTM assay. a: Hypnospores in the RFTM supernatant; b: Trophozoite showing the typical signet ring stage on $4^{\text {th }}$ day; $c$ and d: Signet ring stage on $5^{\text {th }}$ and $6^{\text {th }}$ day; e: Maturing zoosporangia containing numerous internal zoospores; f: Zoosporangium containing numerous zoospores, some leaving the sporangium by the discharge tube $($ Scale bar $=20 \mu \mathrm{m})$ 


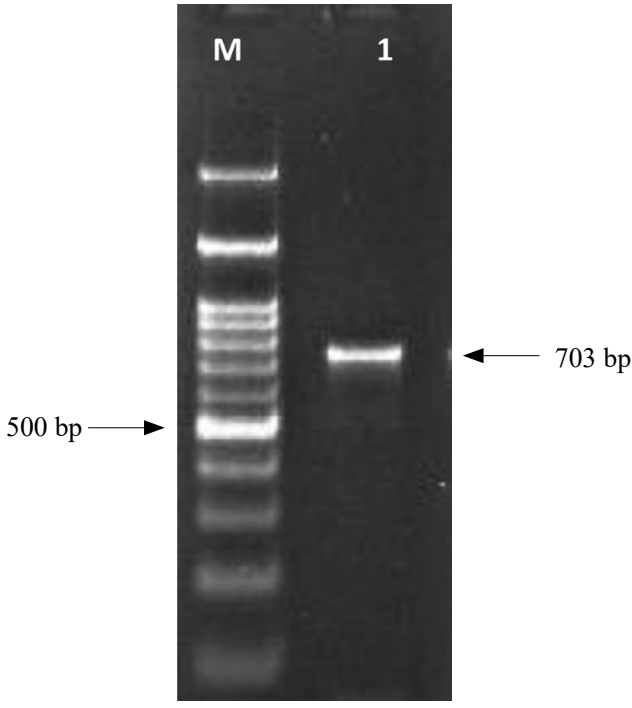

Fig. 4. PCR amplification of ITS region of Perkinsus sp. from M. bilineata. Lanes M - 100 bp DNA marker, 1 - PCR amplified product (703 bp) infecting $M$. bilineata from Pulicat Lake. At present two species of Perkinsus have been reported from India viz., P. olseni in Pinctada fucata (Sanil et al., 2010), Paphia malabarica (Shamal et al., 2018) and P. beihaiensis in M. bilineata ( $=C$. madrasensis) (Sanil et al., 2012). While there is a preliminary report of $P$. marinus infection in M. bilineata $(=C$. madrasensis) from Tuticorin (Muthiah and Nayar, 1988), Sanil et al. (2010) speculated that the report could be a possible misidentification for $P$. olseni or P. beihaiensis (Indian/Brazilian, Group B). The report of P. marinus by Muthiah and Nayar (1988) was based only upon RFTM analysis and lacked molecular confirmation. RFTM analysis is a well established preliminary diagnostic method for identification of Perkinsus sp. (Villalba et al., 2004). In the present study, the hypnospore, 'signet ring' stage of the trophozoites and zoospores observed in the RFTM analysis is supportive for the above fact. Histological analysis also revealed the presence of trophozoites in the gills and muscles. Parasite stages, schizonts and trophozoites were mostly observed in histological sections

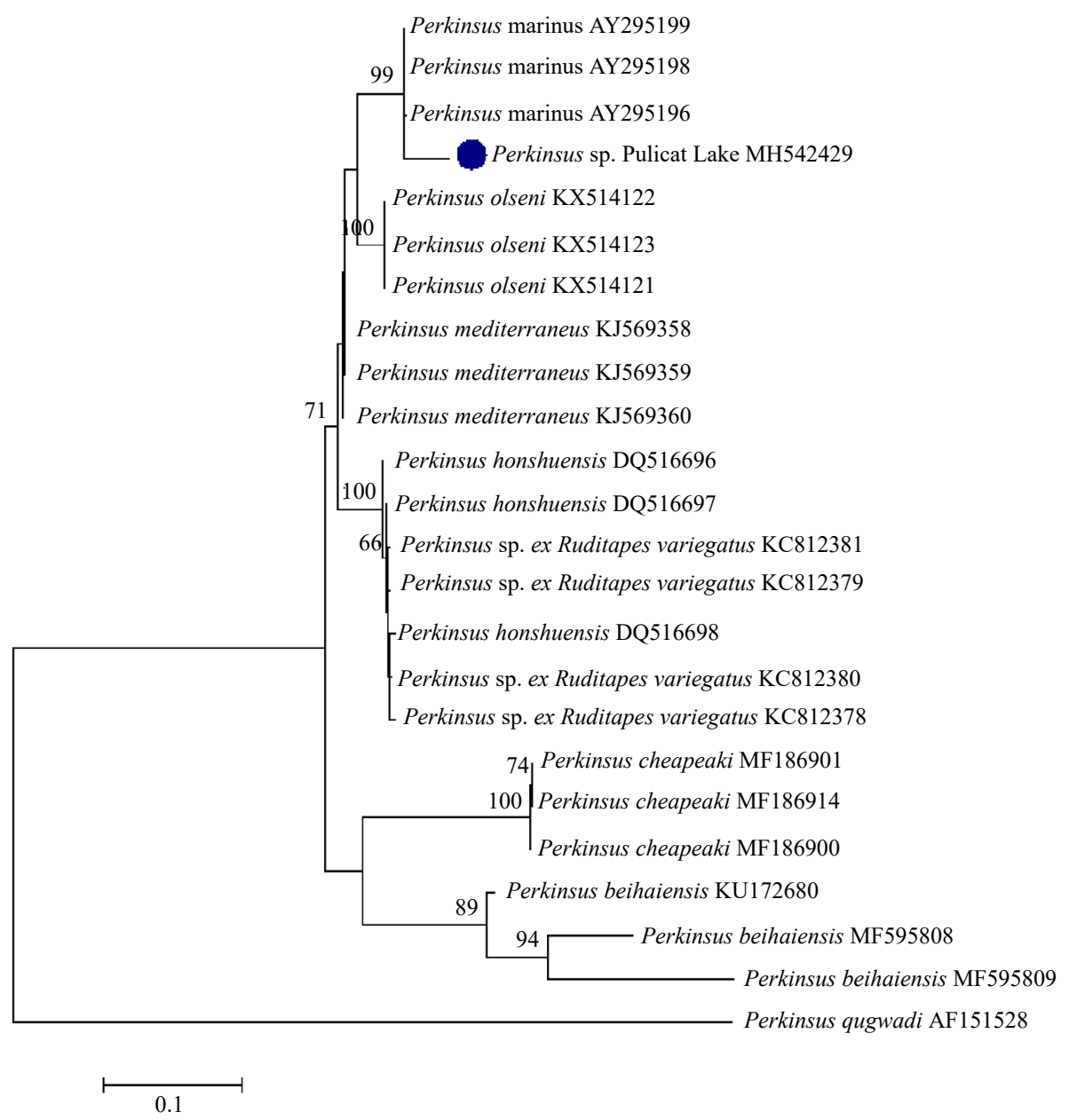

Fig. 5. Phylogenetic position of Perkinsus sp. from Pulicat Lake based on maximum likelihood analysis. Values along the nodes are percent bootstraps for 1000 iterations. (Blue circle indicates the GenBank accession number generated in the present study) 
of the connective tissue, especially adjacent to the epithelial lining of the stomach, among the digestive tubules and in the muscles of $M$. bilineata (=C. madrasensis) (Sanil et al., 2012). Clusters of trophozoites of P. olseni were observed in the gill and mantle tissues of Paphia malabarica, which was demarcated by a clear zone from surrounding tissues (Shamal et al., 2018).

Brown et al. (2004) reported that the intra-specific variation among sequences within a Perkinsus sp. ranges from 0 to $3 \%$ and among species, differences range from approximately $4-14 \%$. Similar findings were noted in the present study where a pair-wise sequence difference of $3 \%$ with the known $P$. marinus sequences was observed and the phylogenetic tree demonstrates the present species to be forming a clade together with $P$. marinus. The present findings need further research on the study of the ultrastructure and different stages of the parasite in comparison with the known described species of Perkinsus. As there is pair-wise sequence distance of $3 \%$ with the known P. marinus sequences, the isolated Perkinsus sp. may indicate an undescribed species.

Pulicat Lake is the second largest brackishwater lake in India and rich diversity of cultivable molluscan species occur in this lake, comprising of 4 families and 6 species (Mohan et al., 2013). The edible oyster M. bilineata ( $=C$. madrasensis) is the most extensively distributed bivalve in this lake and is ideally suited for the culture of this oyster (Sanjeeva Raj, 2006). The report of Perkinsus sp. from Pulicat is a significant finding, when considering the health of the commercial molluscs inhabiting the region, as the presence of these parasites may pose a serious threat to their population.

\section{Acknowledgements}

The authors thank Tamil Nadu Dr. J. Jayalalithaa Fisheries University for extending the facilities for the research work. We thankfully acknowledge the Tamil Nadu State Planning Commission for funding support to carry out this research as a part of the TANII project, "E-fish health surveillance and monitoring network to improve fisheries production in Tamil Nadu".

\section{References}

Altschul, S. F., Gish, W., Miller, W., Myers, E. W. and Lipman, D. J. 1990. Basic local alignment search tool. J. Mol. Biol., 215: 03-410. http://dx.doi 10.1016/S00222836(05)80360-2.

Blackbourn, J., Bower, S. M. and Meyer, G. R. 1998. Perkinsus qugwadi sp. nov. (incertae sedis), a pathogenic protozoan parasite of Japanese scallops Patinopecten yessoensis, cultured in British Columbia, Canada. Can J. Zool., 76: 942-953. http://dx.doi.org/10.1139/z98-015.
Brown, G., Hudson, K. L. and Reece, K. S. 2004. Genetic variation at the ITS and ATAN loci among and within cultured isolates of Perkinsus marinus. J. Eukaryot. Microbiol., 51: 312-320.e.

Casas, S. M., Villalba, A. and Reece, K. S. 2002. Study of the perkinsosis of the carpet shell clam Tapes decussatus in Galicia (NW Spain). Identification of the etiological agent and in vitro modulation of zoosporulation by temperature and salinity. Dis. Aquat. Org., 50: 51-65. DOI:10.3354/ dao050051.

Casas, S. M., Grau, A., Reece, K. S., Apakupakul, K., Azevedo, C. and Villalba, A. 2004. Perkinsus mediterraneus sp., a protistan parasite of the European flat oyster Ostrea edulis from the Balearic Islands, Mediterranean Sea. Dis. Aquat. Org., 58: 231-244.

Chu, F. L. E.1996. Laboratory investigations of susceptibility, infectivity and transmission of Perkinsus marinus in oysters. J. Shellfish Res., 15: 57-66.

Dungan, C. F. and Reece, K. S. 2006. In vitro propagation of two Perkinsus spp. parasites from Japanese Manila clams Venerupis philippinarum and description of Perkinsus honshuensis n. sp. J. Eukaryot. Microbiol., 53: 316-326. DOI:10.1111/j.1550-7408.2006.00120.x.

FAO 2017. FAO yearbook of fishery and aquaculture statistics 2015. Food and Agriculture Organisation of the United Nations, Rome, Italy.

Goggin, C. L. and Lester, R. J. G. 1995. Perkinsus, a protistan parasite of abalone in Australia: A review. Mar. Freshw. Res., 46: 639-646. https://doi.org/10.1071/MF9950639.

Kimura, M. 1980. A simple method for estimating evolutionary rate of base substitutions through comparative studies of nucleotide sequences. Mol. Biol. Evol., 16: 111-120. https://doi.org/10.1007/BF01731581.

Kumar, S., Stecher, G. and Tamura, K. 2016. MEGA7: Molecular Evolutionary Genetics Analysis version 7.0 for bigger datasets. Mol. Biol. Evol., 33(7): 1870-1874. https://doi. org/10.1093/molbev/msw054.

Lester, R. J. G. and Davis, G. H. G. 1981. A new Perkinsus species (Apicomplexa, Perkinsea) from the abalone Haliotis ruber. J. Invertebr. Pathol., 37: 181-187. https:// doi.org/10.1016/0022-2011(81)90073-2.

Mackin, J. G., Owen, H. M. and Collier, A. 1950. Preliminary note on the occurrence of a new protistan parasite, Dermocystidium marinum sp. in Crassostrea virginica (Gemlin). Science, 111: 328-329. https://doi.org/10.1126/ science.111.2883.328.

McLaughlin, S. M., Tall, B. D., Shaheen, A., Elsayed, E. E. and Faisal, M. 2000. Zoosporulation of a new Perkinsus species isolated from the gills of the soft shell clam Mya arenaria. Parasite, 7: 115-122.

Mohan, D., Elumalai, V., Subbulakshmi, G., Jayalakshmi, S. and Srinivasan, M. 2013. Biodiversity of cultivable molluscan resources from Pulicat Lake, south-east coast of India. 
Arthropods, 2(2):53-65. https://doi.org/10.0000/issn-22244255-arthropods-2013-v2-0008.

Moss, J. A., Xiao, J., Dungan, C. F. and Reece, K. S. 2008. Description of Perkinsus beihaiensis n. sp., a new Perkinsus sp. parasite in oysters of southern China. J. Eukaryot. Microbiol., 55: 117-130. doi: 10.1111/j.15507408.2008.00314.x.

Muthiah, P. and Nayar, K. N. 1988. Incidence of Perkinsus marinus in Crassostrea madrasensis. Bull. Centr. Mar. Fish. Res. Inst., 43: 232-235.

Nei, M. and Kumar, S. 2000. Molecular evolution and phylogenetics. Oxford University Press, New York, USA. https://doi.org/10.1046/j.1365-2540.2001.0923a.x.

OIE 2006. Manual of diagnostics tests for aquatic animals, $5^{\text {th }}$ edn. Office International des Epizootics, Paris, France.

Perkins, F. O. and Menzel, R. W. 1966. Morphological and cultural studies of a motile stage in the life cycle of Dermocystidium marinum. Proc. Natl. Shellfish. Ass., 56: 23-30.

Perkins, F. O. 1968. Finestructure of zoospores from Labyrinthomyxa sp. parasitizing the clam Macomabalthica chesap. Science, 9: 198-208. https://doi.org/10.2307/1351185.

Perkins, F. O. 1988. Structure of protistan parasites found in bivalve molluscs. In: Fisher, W. (Ed.), Disease processes in marine bivalve molluscs. J. Am. Fish. Soc., 18: 93-111.

Perkins, F. O. 1996. The structure of Perkinsus marinus (Mackin, Owen and Collier, 1950) Levine, 1978 with comments on taxonomy and phylogeny of Perkinsus spp. J. Shellfish Res., 15: 67-70.

Ray, S. M. 1952. A culture technique for the diagnosis of infections with Dermocystidium marinum Mackin, Owen, and Collier in oysters. Science, 116(3014): 360-361. doi: 10.1126/science.116.3014.360.

Ray, S. M. 1954. Biological studies of Dermocystidium marinum, a fungus parasite of oysters. Doctoral Disseration, Rice University, USA. https://hdl.handle.net/1911/18411.

Ray, S. M. 1966. A review of the culture method for detecting Dermocystidium marinum with suggested modifications and precautions. Proc. Natl. Shellfish Ass., 54: 55-69.

Roding P. F. 1798. Museum Boltenianum sive Catalogus cimeliorum e tribus regnis naturæ quæ olim collegerat Joa. Fried Bolten, M. D. p. d. per XL. annos proto physicus
Hamburgensis. Pars secunda continens Conchylia sive Testacea univalvia, bivalvia and multivalvia. Trapp, Hamburg. viii, 199 pp. https://www.biodiversitylibrary. org/page/ 16230659.

Roberts, R. J. 2012. Fish pathology, $4^{\text {th }}$ edn. John Wiley and Sons, UK, $590 \mathrm{pp}$.

Sanil, N. K., Vijayan, K. K., Kripa, V. and Mohamed, K. S. 2010. Occurrence of the protozoan parasite Perkinsus olseni in the wild and farmed pearl oyster Pinctada fucata (Gould) from the Southeast coast of India. Aquaculture, 299(1-4): 8-14. https://doi.org/10.1016/ j.aquaculture.2009.12.007.

Sanil, N. K., Suja, G., Lijo, J. and Vijayan, K. K. 2012. First report of Perkinsus beihaiensis in Crassostrea madrasensis from the Indian subcontinent. Dis. Aquat. Org., 98: 209-220. https://doi.org/10.3354/dao02440.

Shamal, P., Zacharia, P. U., Binesh, C. P., Pranav, P., Suja, G., Asokan, P. K., Pradeep, M. A., Rithesh, R., Vijayan, K. K. and Sanil, N. K. 2018. Perkinsus olseni in the shortneck yellow clam, Paphia malabarica (Chemnitz, 1782) from the southwest coast of India. J. Invertebr. Pathol., 159: 113-120. doi: 10.1016/j.jip.2018.10.001.

Soniat, T. M. 1996. Epizootiology of Perkinsus marinus disease of eastern oysters in the Gulf of Mexico. J. Shellfish Res., 15: 35-43.

Sanjeeva Raj, P. J. 2006. Macro fauna of Pulicat Lake, NBA Bulletin No. 6, National Biodiversity Authority, Chennai, Tamil Nadu, India, 67 pp.

Thompson, J. D., Higgins, D. G. and Gibson, T. J. 1994. CLUSTAL W: Improving the sensitivity of progressive multiple sequence alignment through sequence weighting, position-specific gap penalties and weight matrix choice. Nucleic Acids Res., 22(22): 4673-4680. https://doi. org/10.1093/nar/22.22.4673.

Villalba, A., Reece, K. S., Ordas, M. C., Casas, S. M. and Figueras, A. 2004. Perkinsosis in molluscs: A review. Aquat. Living Resour., 17: 411-432. https://doi.org/10.1051 /alr:200 4050

Yadavalli, R., Umeda, K. and Robeldo, J. A .F. 2020. Perkinsus marinus. Trends Parasitol., 36(12): 1013-1014. https://doi. org/10.1016/j.pt.2020.05.002. 